DOI:10.17951/h.2016.50.1.159

\begin{tabular}{lcc}
\hline \multicolumn{3}{c}{ A N N A L E S } \\
UNIVERSITATIS MARIAE CURIE-SKŁODOWSKA \\
LUBLIN - POLONIA \\
VOL. L, $1 \quad$ SECTIOH \\
\hline
\end{tabular}

Szkoła Główna Handlowa w Warszawie. Kolegium Ekonomiczno-Społeczne

\title{
BARBARA WOŹNIAK
}

barbara.wozniak@sgh.waw.pl

\section{Podatkowe instrumenty pomocy publicznej*}

Fiscal State Aid Instrument

Słowa kluczowe: pomoc publiczna; pomoc de minimis; podatkowe instrumenty pomocy; pomoc czynna; pomoc bierna

Keywords: state aid; de minimis aid; fiscal aid instrument; active state aid instrument; passive state aid instrument

Kod JEL: E62; H29; H39

\section{Wstęp}

Państwa członkowskie Unii Europejskiej mogą udzielać wsparcia przedsiębiorcom, z wykorzystaniem środków publicznych, w granicach wyznaczonych regulacjami prawa unijnego, tak traktatowego, jak i wtórnego [por. Woźniak, 2008, s. 248 i n.]. Te granice zakreślają obszar dopuszczalnej pomocy publicznej (pomocy państwa), stanowiącej szczególną formę interwencji państwa w gospodarkę ${ }^{1}$. Pomoc publiczna oznacza przysporzenie korzyści finansowych określonemu przedsiębiorcy, dających mu przewagę konkurencyjną. Zakłóca zatem działanie mechanizmu rynkowego i wpływa

\footnotetext{
* Artykuł został sfinansowany ze środków Narodowego Centrum Nauki przyznanych na podstawie decyzji nr DEC-2013/B/HS4/03610.

1 Zarówno samo pojęcie pomocy publicznej, jak i zasady jej dopuszczalności są stale poddawane kontroli i objaśnianiu [zob. np. Komunikat Komisji..., 2014].
} 
na wymianę handlową między państwami członkowskimi, dlatego Unia Europejska prowadzi wspólną politykę udzielania pomocy publicznej, określając zasady kontroli pomocy dopuszczalnej i eliminowania pomocy niedopuszczalnej. Polityka udzielania pomocy publicznej obejmuje taki obszar polityki fiskalnej, w którym zakres suwerenności polityki narodowej jest wąski i ogranicza się do podejmowania działań wewnętrznych w ramach wyznaczonych przez ogólne założenia wspólnej polityki konkurencji [Woźniak, 2012, s. 163 i n.]. Prowadzenie określonej polityki jest zawsze związane $\mathrm{z}$ wykorzystywaniem określonych instrumentów, a w przypadku pomocy publicznej - instrumentów pomocy czynnej (aktywnej) i biernej (pasywnej).

Celem opracowania jest próba odpowiedzi na pytania, czy instrumenty podatkowe są dominującą formą udzielania biernej pomocy publicznej w Polsce i czy taka pomoc ma charakter prorozwojowy. W poszukiwaniu odpowiedzi na tak sformułowane pytania badawcze wykorzystamy metodę analizy dynamiki i struktury biernej pomocy publicznej, która jest udzielana przy pomocy instrumentów podatkowych i parapodatkowych ${ }^{2}$. Analizę wybranych form wspierania przedsiębiorstw przeprowadzimy w kontekście ogólnej pomocy publicznej oraz pomocy de minimis.

\section{Instrumenty udzielania pomocy publicznej}

Pomoc publiczna jest udzielana w różnych celach i w różnych formach. Pomoc czynna polega na przekazaniu przedsiębiorcom środków wsparcia zasilających ich aktywa finansowe bądź rzeczowe, np. w formie dotacji z budżetu państwa (wydatki publiczne). Pomoc bierna oznacza zmniejszenie ciężaru danin publicznych lub zaniechanie ich poboru i pozostawienie środków $\mathrm{z}$ tego tytułu w dyspozycji przedsiębiorców (uszczuplenie wpływu należnych środków do funduszy publicznych, np. do budżetu państwa). Pomoc bierna może być udzielana zgodnie z intencją władz publicznych (np. przez wprowadzenie ulg i zwolnień podatkowych) lub może być wymuszona trudną sytuacją, w jakiej znalazł się przedsiębiorca (np. umorzenie zadłużenia przedsiębiorstwa $\mathrm{z}$ tytułu zaległości podatkowych względem budżetu państwa lub budżetu jednostki samorządu terytorialnego, JST). W pierwszym przypadku podatkowe instrumenty pomocy mogą być wykorzystane np. jako zachęta do realizacji konkretnych inwestycji w konkretnym regionie, w drugim - raczej w celu ratowania i restrukturyzacji przedsiębiorstw.

System monitorowania pomocy publicznej w Polsce posługuje się unijną klasyfikacją form pomocy, według której wyróżnia się cztery grupy pomocy publicznej: dotacje i ulgi podatkowe, subsydia kapitałowo-inwestycyjne, tzw. miękkie kre-

2 W raportach o pomocy publicznej w Polsce udzielonej przedsiębiorcom w kolejnych latach, przygotowywanych przez UOKiK i stanowiących podstawę do przeprowadzenia tej analizy, brakuje pełnego rozróżnienia tych dwu grup instrumentów pomocy biernej, dlatego w opracowaniu przedstawiono tylko dane dotyczące instrumentów stricte podatkowych, które były dostępne. 
dytowanie oraz poręczenia i gwarancje. Grupy te oznaczono literami A, B, C i D. W ramach każdej grupy pomoc dodatkowo dzieli się na czynną (oznaczoną cyfrą 1) i bierną (oznaczoną cyfrą 2).

Grupa A (A1 i A2) obejmuje dotacje i ulgi podatkowe, przy czym do podgrupy A1 należą np. dotacje, refundacje, rekompensaty, natomiast do podgrupy A2 - instrumenty stricte podatkowe, parapodatkowe oraz inne. Wśród instrumentów podatkowych należy wymienić: zwolnienie z podatku, odliczenie od podatku, obniżkę lub zmniejszenie powodujące obniżenie podstawy opodatkowania lub wysokości podatku, zaniechanie poboru podatku, umorzenie zaległości podatkowej wraz z odsetkami, umorzenie odsetek od zaległości podatkowej. Instrumenty parapodatkowe to: obniżenie wysokości opłaty, zwolnienie z opłaty, zaniechanie poboru opłaty, umorzenie opłaty i odsetek za zwłokę z tytułu opłaty (składki, wpłaty). Inne rodzaje instrumentów udzielania pomocy publicznej obejmują: umorzenie kar, oddanie do korzystania mienia będącego własnością Skarbu Państwa lub JST i ich związków na warunkach korzystniejszych dla przedsiębiorcy od oferowanych na rynku, zbycie mienia będącego własnością Skarbu Państwa lub jednostek samorządu terytorialnego i ich związków na warunkach korzystniejszych od oferowanych na rynku, umorzenie kosztów egzekucyjnych, umorzenie kosztów procesu sądowego, jednorazową amortyzację.

Grupa C (C1 i C2) - miękkie kredytowanie - obejmuje instrumenty pomocy czynnej $\mathrm{C} 1$ i biernej $\mathrm{C} 2$. Do podgrupy $\mathrm{C} 1$ należą: pożyczki, kredyty preferencyjne, dopłaty do oprocentowania kredytów bankowych (dla banków), pożyczki warunkowo umorzone. Natomiast do podgrupy $\mathrm{C} 2$ zalicza się instrumenty podatkowe, $\mathrm{tj}$. odroczenie lub rozłożenie na raty płatności podatku lub zaległości podatkowej wraz z odsetkami za zwłokę oraz pozostałe instrumenty, czyli odroczenie lub rozłożenie na raty płatności opłaty (składki, wpłaty), odroczenie lub rozłożenie na raty płatności zaległej opłaty (składki, wpłaty) lub zaległej opłaty (składki, wpłaty) wraz z odsetkami, odroczenie lub rozłożenie na raty płatności kary, odroczenie lub rozłożenie na raty kosztów egzekucyjnych, odroczenie lub rozłożenie na raty odsetek, odroczenie lub rozłożenie na raty kosztów procesu sądowego.

Jak widać, wachlarz instrumentów pomocy publicznej w podgrupie A2, nazywanej ulgami (subsydiami) podatkowymi, oraz w podgrupie $\mathrm{C} 2$ jest bardzo szeroki i obejmuje nie tylko instrumenty podatkowe. Zakładamy jednak, że instrumenty podatkowe są dominującą formą biernej pomocy publicznej i jej przede wszystkim poświęcimy uwagę w dalszych rozważaniach.

\section{Dynamika i struktura biernej pomocy publicznej}

$\mathrm{Z}$ danych zawartych w tab. 1 i 2 wynika, że dominującą formą pomocy w grupach A i C są instrumenty pomocy czynnej A1 i C1. Udział ulg podatkowych (A2) w ogólnej pomocy publicznej (z wyłączeniem transportu i pomocy de minimis, a także pomocy udzielonej w sektorze rolnictwa) systematycznie obniżał się z poziomu 
22,7\% w 2007 r. do 8,7\% w 2013 r., czyli poziomu dziesięciokrotnie niższego niż w grupie A1. Natomiast odroczenie lub rozłożenie na raty płatności podatkowych oraz parapodatkowych (C2) jedynie w 2008 r. stanowiło $2 \%$ pomocy publicznej (224,9 $\mathrm{mln}$ zł) - więcej niż pożyczki i kredyty preferencyjne oraz pozostałe instrumenty grupy $\mathrm{C} 1$ wykorzystane w tym roku.

Tab. 1. Ogólna pomoc publiczna w latach 2007-2013 (z wyłączeniem transportu i pomocy de minimis, a także pomocy udzielonej w sektorze rolnictwa)

\begin{tabular}{|c|c|c|c|c|c|c|c|}
\hline & \multicolumn{7}{|c|}{ Wartość pomocy w mln zł } \\
\hline & 2007 & 2008 & 2009 & 2010 & 2011 & 2012 & 2013 \\
\hline Pomoc ogółem & 4847,2 & 11521,9 & 16087,2 & 21235,5 & 17955,1 & 18054,9 & 16571,70 \\
\hline $\begin{array}{l}\text { Grupa A, } \\
\text { w tym: }\end{array}$ & 4746,2 & 9380,9 & 13741,5 & 19397,4 & 17532,7 & 17188,5 & 16205,70 \\
\hline A1 & 3644,1 & 7338,8 & 11323,2 & 16447,9 & 15358,1 & 15347,1 & 14760,70 \\
\hline A2 & 1102,1 & 2042,1 & 2418,2 & 2949,4 & 2174,5 & 1841,4 & 1445,00 \\
\hline $\begin{array}{l}\text { Grupa C, } \\
\text { w tym: }\end{array}$ & 66,8 & 348,1 & 191,9 & 338,5 & 159,3 & 736,1 & 317,90 \\
\hline $\mathrm{C} 1$ & 66,5 & 123,2 & 191,6 & 338,4 & 155,5 & 736,0 & 317,90 \\
\hline $\mathrm{C} 2$ & 0,3 & 224,9 & 0,3 & 0,2 & 3,8 & 0,1 & 0,01 \\
\hline
\end{tabular}

Źródło: opracowanie własne na podstawie raportów o pomocy publicznej w Polsce udzielanej przedsiębiorcom w poszczególnych latach, UOKiK.

Tab. 2. Dynamika i struktura ogólnej pomocy publicznej w Polsce (z wyłączeniem transportu i pomocy de minimis, a także pomocy udzielonej w sektorze rolnictwa)

\begin{tabular}{|c|c|c|c|c|c|c|c|c|c|c|c|c|c|}
\hline & \multicolumn{6}{|c|}{ Dynamika (rok poprzedni=100) } & \multicolumn{7}{|c|}{ Udział w \% * } \\
\hline & '08/'07 & '09/’08 & '10/'09 & '11/'10 & '12/'11 & '13/'12 & 2007 & 2008 & 2009 & 2010 & 2011 & 2012 & 2013 \\
\hline $\begin{array}{l}\text { moc } \\
\text { ółem }\end{array}$ & 237,7 & 139,6 & & 84,6 & 100,6 & 91,8 & 100,0 & 100,0 & 100,0 & 100,0 & 100,0 & 100,0 & 1000 \\
\hline $\begin{array}{l}\text { Grupa } A \text {, } \\
\text { w tym: }\end{array}$ & 197,7 & 146,5 & 141,2 & 90,4 & 98,0 & 94,3 & 97,9 & 81,4 & 85,4 & 91,3 & 97,6 & 95,2 & 97,8 \\
\hline & 01,4 & & & & 99,9 & & 75,2 & 63,7 & 70,4 & 77,5 & 85,5 & 0 & 89,1 \\
\hline $\mathrm{A} 2$ & 185,3 & 118,4 & & 73,7 & 84,7 & 78,5 & 22,7 & 17,7 & 15,0 & 13,9 & 12,1 & 10,2 & 8 , \\
\hline $\begin{array}{l}\text { Grupa } C \text {, } \\
\text { w tym: }\end{array}$ & 521,1 & 55,1 & 176,4 & 47,1 & 452,1 & 43,2 & 1,4 & 3,0 & 1,2 & 1,6 & 0,9 & 4,1 & 1, \\
\hline $\mathrm{C} 1$ & 185,3 & 155,5 & 176,6 & 46,0 & 473,3 & 43,2 & 1,4 & 1,1 & 1,2 & 1,6 & 0,9 & 4,1 & 1 , \\
\hline $\mathrm{C} 2$ & 74966,7 & 0,1 & 60,0 & 1900,0 & 2,3 & 10,4 & 0,01 & 2,0 & 0,002 & 0,001 & 0,02 & 0,001 & 0,000 \\
\hline
\end{tabular}

* udziały w grupach nie zawsze sumują się z powodu zaokrągleń

Źródło: opracowanie własne na podstawie raportów o pomocy publicznej w Polsce udzielanej przedsiębiorcom w poszczególnych latach, UOKiK.

Przeważającą część tej pomocy udzielił ZUS w formie rozłożenia na raty należnych wpłat (instrumentów parapodatkowych) dwóm podmiotom: Kompanii Węglowej S.A. (217,2 mln zł) oraz Bytomskiej Spółce Restrukturyzacji Kopalń (7,6 mln zł). Taka pomoc była ukierunkowana raczej na ratowanie i restrukturyzację, a nie na cele prorozwojowe. Podobna sytuacja była w $2011 \mathrm{r}$., gdy gwałtowny wzrost pomocy w grupie $\mathrm{C} 2$ wiązał się z udzieleniem Krakowskim Zakładom Garbarskim 
S.A. pomocy na restrukturyzację $(3,4 \mathrm{mln}$ zł $) \mathrm{w}$ formie odroczenia terminu płatności i rozłożenia na raty zaległości podatkowej wraz z odsetkami. W pozostałych latach instrumenty grupy $\mathrm{C} 2$ były tylko sporadycznie wykorzystywane.

Tab. 3. Formy ogólnej pomocy publicznej (z wyłączeniem transportu i pomocy de minimis, a także pomocy udzielonej w sektorze rolnictwa)

\begin{tabular}{|l|c|c|c|c|}
\hline \multirow{2}{*}{ Rok } & \multicolumn{2}{|c|}{ Wartość pomocy w mln zł } & \multicolumn{2}{c|}{ Udział form pomocy w \% } \\
\cline { 2 - 5 } & $\mathrm{A} 2+\mathrm{C} 2$ & Pozostałe formy & A2+C2 & Pozostałe formy \\
\hline 2007 & 1102,4 & 3744,8 & 22,74 & 77,26 \\
\hline 2008 & 2267,0 & 9254,9 & 19,68 & 80,32 \\
\hline 2009 & 2418,5 & 13668,7 & 15,03 & 84,97 \\
\hline 2010 & 2949,6 & 18285,9 & 13,89 & 86,11 \\
\hline 2011 & 2178,3 & 15776,8 & 12,13 & 87,87 \\
\hline 2012 & 1841,5 & 16213,4 & 10,20 & 89,80 \\
\hline 2013 & 1445,0 & 15126,7 & 8,72 & 91,28 \\
\hline
\end{tabular}

Źródło: opracowanie własne na podstawie raportów o pomocy publicznej w Polsce udzielanej przedsiębiorcom w poszczególnych latach, UOKiK.

Biorąc pod uwagę całą grupę analizowanych instrumentów pomocy biernej (A2+C2) łatwo zauważyć, że w okresie 2007-2013 odgrywały one coraz mniejszą rolę w szerokim wachlarzu dostępnych instrumentów udzielania pomocy publicznej (tab. 3). Wartość udzielonego w tej formie wsparcia dla przedsiębiorstw wzrastała do 2010 r., podobnie jak ogólna wartość pomocy publicznej, a od 2011 r. charakteryzuje się tendencją spadkową. W latach 2011-2013 ponad 90\% pomocy w formie subsydiów podatkowych (A2) udzielili dyrektorzy izb skarbowych i celnych oraz naczelnicy urzędów skarbowych i celnych, natomiast od 5\% do 7,6\% stanowiła pomoc w tej formie udzielona przez prezydentów i burmistrzów miast oraz wójtów gmin. Wśród pozostałych podmiotów udzielających pomocy w tej formie można jeszcze wyróżnić marszałków województw i starostów powiatów oraz prezesa PFRON. Taki rozkład podmiotów udzielających pomocy biernej w formie ulg podatkowych (A2) świadczy o dominacji instrumentów podatkowych w tej grupie.

W latach 2011-2013 pomocy w formie odroczenia lub rozłożenia na raty płatności (C2) udzielały te same podmioty co w podgrupie A2, tylko w innej wielkości. W 2011 r. prawie 49\% wsparcia w tej formie stanowiła pomoc prezydentów i burmistrzów miast oraz wójtów gmin, a $31 \%$ to pomoc udzielona przez organy skarbowe. Te podmioty wykorzystują głównie podatkowe instrumenty pomocy publicznej. W następnych latach wsparcia w formie $\mathrm{C} 2$ udzielał ZUS oraz przedsiębiorcy, a więc wykorzystywano głównie parapodatkowe instrumenty pomocy.

Tendencje zmian zarówno dynamiki, jak i struktury pomocy publicznej w grupach A2 i C2 należy uznać za korzystne, ponieważ jest to pomoc mniej przejrzysta niż pomoc udzielana $\mathrm{w}$ formie dotacji oraz pozostałych instrumentów pomocy czynnej. Przejrzystość pomocy trzeba odnosić tu zarówno do możliwości oszacowania jej wielkości (ekwiwalentu dotacji brutto) przed notyfikacją i skierowaniem do beneficjenta, jak i do możliwości oceny przewidywanych efektów jej udzielenia. Jest to 
szczególnie istotne, gdy rozpatruje się możliwość udzielenia wsparcia przedsiębiorcom w ramach wyłączeń grupowych, a więc bez konieczności notyfikacji pomocy ex ante ${ }^{3}$. Dlatego pomoc publiczna udzielana przy pomocy instrumentów podatkowych i parapodatkowych jest rzadziej wykorzystywana w celu oddziaływania na przedsiębiorców. Komisja Europejska, w ramach dyskrecjonalnej polityki udzielania pomocy publicznej, również preferuje instrumenty dopuszczalnej pomocy czynnej.

Jest jeszcze inny aspekt tego problemu, na który warto zwrócić uwagę. Instrumenty pomocy publicznej są wykorzystywane do udzielania przedsiębiorcom wsparcia o charakterze prorozwojowym, w celu np. wykreowania nowych możliwości biznesowych, oraz wsparcia antykryzysowego nastawionego na cele ratunkowe i restrukturyzacyjne [Jurkowska-Gomułka, 2014, s. 97, 98]. Wsparcie prorozwojowe jest skierowane do podmiotów dobrze rokujących, mających perspektywiczne możliwości rozwoju, i jest udzielane głównie z wykorzystaniem instrumentów pomocy czynnej. Natomiast drugi rodzaj pomocy jest kierowany raczej ex post do podmiotów zagrożonych, znajdujących się w złej sytuacji ekonomicznej, z wykorzystaniem głównie instrumentów pomocy biernej. Świadczą o tym przywołane wcześniej przykłady pomocy w grupie $\mathrm{C} 2$.

W UE od 2000 r. następowały zmiany w kierunku odchodzenia od pomocy antykryzysowej na rzecz pomocy prorozwojowej. Kryzys finansowy spowodował od 2008 r. zmianę priorytetów w kierunku pakietu antykryzysowego dla sektora finansowego, ale - jak wiadomo - takie działania powinny mieć charakter tymczasowy, dlatego polityka w zakresie udzielania pomocy publicznej powinna być ukierunkowana na cele rozwojowe, z przewagą pomocy czynnej, i takie tendencje obserwujemy w Polsce.

Nie można jednak generalizować wskazanych powyżej uwarunkowań i zależności, ponieważ nie zawsze sprawdzają się w praktyce. $Z$ badań przeprowadzonych przez A.A. Ambroziaka wynika, że przedsiębiorcy funkcjonujący w specjalnych strefach ekonomicznych (SSE) wyżej oceniali fiskalne instrumenty pomocy publicznej: zwolnienia od podatku dochodowego i podatku od nieruchomości oraz zmniejszenie kosztów zatrudnienia pracowników, niż bezpośrednie zasilenia w formie dotacji (grantów) [Ambroziak, 2009, s. 431]. Co więcej, zwolnienia podatkowe w przypadku SSE można uważać za pomoc publiczną o charakterze prorozwojowym, przyciągającą inwestycje, o wysokim prawdopodobieństwie uzyskania oczekiwanych efektów, ponieważ przedsiębiorca funkcjonujący w strefie korzysta ze zwolnień podatkowych dopiero po uruchomieniu produkcji i uzyskaniu dochodu. W przypadku pomocy czynnej nie ma pewności, że inwestycja zostanie w całości zrealizowana, a jej przewidywane efekty zostaną w pełni osiągnięte.

3 Aktualne zasady stosowania wyłączeń grupowych przedstawia Rozporządzenie Komisji (UE) nr 651/2014 z dnia 17 czerwca 2014 r. uznające niektóre rodzaje pomocy za zgodne z rynkiem wewnętrznym w zastosowaniu art. 107 i 108 Traktatu (Dz. U. UE L 187, 26.06.2014) [s. 1]. 
Zwolnienia podatkowe w SSE, wykorzystywane jako zachęty inwestycyjne dla przedsiębiorców, wpływają na wzrost produkcji, a w przypadku nowych inwestycji - na utworzenie nowych lub utrzymanie istniejących miejsc pracy [Ambroziak, 2009, s. 428]. Uszczuplenie wpływów budżetowych w wyniku stosowania zwolnień w podatku dochodowym może zatem zostać zrekompensowane wzrostem dochodów budżetowych z tytułu opodatkowania pośredniego wzrostu produkcji. Utworzenie nowych i utrzymanie istniejących miejsc pracy przynosi korzyści także w postaci zmniejszenia obciążeń budżetu wypłatą zasiłków dla bezrobotnych i zwiększenia wpływów z podatków pośrednich.

Podatkowe instrumenty pomocy publicznej mogą mieć zatem charakter prorozwojowy, szczególnie gdy są wykorzystywane jako regionalna pomoc inwestycyjna udzielana przez JST w celu aktywizacji gospodarczej regionu.

\section{Analiza instrumentów pomocy de minimis}

Wsparcie udzielane przedsiębiorcom obejmuje nie tylko pomoc publiczną określoną $\mathrm{w}$ art. 107 TFUE, ale również tzw. pomoc de minimis nieuwzględnianą $\mathrm{w}$ danych analizowanych wcześniej (tab. 1-3). Pomoc de minimis ze względu na niską wartość nie wpływa na handel między państwami członkowskimi UE, nie zakłóca bądź nie zagraża zakłóceniem konkurencji i nie podlega obowiązkowej notyfikacji. Łączna kwota pomocy de minimis dla danego beneficjenta nie może przekroczyć 200 tys. euro w okresie trzech kolejnych lat podatkowych (100 tys. euro w sektorze transportu drogowego i 500 tys. euro w zakresie finansowania usług świadczonych w ogólnym interesie gospodarczym).

Tab. 4. Pomoc de minimis w latach 2007-2013

\begin{tabular}{|c|c|c|c|c|c|c|c|}
\hline & \multicolumn{7}{|c|}{ Wartość pomocy w mln zł } \\
\hline & 2007 & 2008 & 2009 & 2010 & 2011 & 2012 & 2013 \\
\hline Pomoc ogółem & 970,3 & 1159,5 & 3335,2 & 4618,6 & 3418,6 & 4315,6 & 6143,1 \\
\hline $\begin{array}{l}\text { Grupa A, } \\
\text { w tym: }\end{array}$ & b.d. & 1066,9 & 3208,6 & 4462,3 & 3226,2 & 4034,2 & 4780,1 \\
\hline \begin{tabular}{l|l|} 
& A1 \\
\end{tabular} & b.d. & 815,9 & 2865,3 & 4148,5 & 2840,7 & 3790,2 & 4493,9 \\
\hline A2 & b.d. & 251,0 & 343,3 & 313,8 & 385,5 & 244,0 & 286,2 \\
\hline $\begin{array}{l}\text { Grupa C, } \\
\text { w tym: }\end{array}$ & b.d. & 67,6 & 89,7 & 85,2 & 83,5 & 107,0 & 185,9 \\
\hline $\mathrm{C} 1$ & b.d. & 38,4 & 41,1 & 39,3 & 52,5 & 47,2 & 103,7 \\
\hline $\mathrm{C} 2$ & b.d. & 29,2 & 48,6 & 45,9 & 31,0 & 59,8 & 82,2 \\
\hline
\end{tabular}

Źródło: opracowanie własne na podstawie raportów o pomocy de minimis w Polsce udzielanej przedsiębiorcom w poszczególnych latach, UOKiK.

Z porównania danych zaprezentowanych w tab. 4 i tab. 1 wynika, że wartość pomocy de minimis udzielonej w poszczególnych latach była znacznie niższa niż ogólnej pomocy publicznej: w 2007 r. prawie pięciokrotnie, a w 2013 r. ponad dwuipółkrotnie. 
Jednak kwoty pomocy de minimis udzielanej w formie odroczenia lub rozłożenia na raty płatności podatkowych i parapodatkowych (grupa C2) były od 2009 r. wyższe niż ogólnej pomocy publicznej (tab. 1). W 2009 r. pomoc de minimis wykorzystująca te instrumenty osiągnęła wartość 48,6 mln zł, a w kolejnych latach zmalała do 45,9 $\mathrm{mln}$ zł w 2010 r. i 31,0 mln zł w 2011 r., by następnie wzrosnąć do 59,8 mln zł w 2012 r. i 82,2 mln zł w 2013 r. W tym czasie wartość ogólnej pomocy publicznej w grupie C2 wahała się od 0,3 mln zł w 2009 r. i 3,8 mln zł w 2011 r. do 0,01 mln zł w 2013 r.

Przyczyny takich różnic są oczywiste, ponieważ pomoc de minimis ma określony górny pułap wysokości, którego przekroczenie oznacza przejście do złożonych procedur oceny dopuszczalności pomocy i konieczności jej notyfikacji ex ante. Dlatego tą formą pomocy zainteresowani są głównie mikro-, mali i średni przedsiębiorcy. W 2013 r. ponad 96\% pomocy de minimis udzielono właśnie tej grupie przedsiębiorców, w tym mikroprzedsiębiorcom aż 69\%. Do nich skierowana była pomoc w formie odroczenia lub rozłożenia na raty płatności podatkowych i parapodatkowych $(\mathrm{C} 2)$, służąca rozwiązywaniu ich bieżących problemów ekonomicznych. Taka pomoc z reguły nie ma charakteru prorozwojowego, lecz jest wykorzystywana do ratowania i restrukturyzacji przedsiębiorstw tej grupy, dlatego podlega silnym wahaniom z roku na rok, tak pod względem dynamiki, jak i struktury. Natomiast ulgi i zwolnienia podatkowe (grupa A2) mogą sprzyjać rozwojowi przedsiębiorstw, są częściej wykorzystywane i z tego powodu obejmują większą część pomocy de minimis. W 2009 r. pomoc w tej formie wyniosła 343,3 mln zł, a w 2013 r. - 286,2 mln zł.

Tab. 5. Formy pomocy de minimis

\begin{tabular}{|c|c|c|c|c|}
\hline \multirow{2}{*}{ Rok } & \multicolumn{2}{|c|}{ Wartość pomocy w mln zł } & \multicolumn{2}{c|}{ Udział form pomocy w \% } \\
\cline { 2 - 5 } & $\mathrm{A} 2+\mathrm{C} 2$ & Pozostałe formy & $\mathrm{A} 2+\mathrm{C} 2$ & Pozostałe formy \\
\hline 2008 & 280,2 & 879,3 & 24,17 & 75,83 \\
\hline 2009 & 391,9 & 2943,3 & 11,75 & 88,25 \\
\hline 2010 & 359,7 & 4258,9 & 7,79 & 92,21 \\
\hline 2011 & 416,5 & 3002,1 & 12,18 & 87,82 \\
\hline 2012 & 303,8 & 4011,8 & 7,04 & 92,96 \\
\hline 2013 & 368,4 & 5774,7 & 6,00 & 94,00 \\
\hline
\end{tabular}

Źródło: opracowanie własne na podstawie raportów o pomocy de minimis w Polsce udzielanej przedsiębiorcom w poszczególnych latach, UOKiK.

Łączna wartość pomocy de minimis udzielonej z wykorzystaniem instrumentów podatkowych i parapodatkowych $(\mathrm{A} 2+\mathrm{C} 2)$ stanowiła ponad $20 \%$ całej pomocy de minimis w 2008 r. (tab. 5). Podobna była struktura ogólnej pomocy publicznej w tym roku, z udziałem instrumentów grupy A2+C2 na poziomie 19,7\% (tab. 3). $\mathrm{W}$ następnych latach pomoc de minimis $\mathrm{w}$ tej formie wykazywała większe wahania w porównaniu z ogólną pomocą publiczną, a udział instrumentów A2+C2 spadł do 6\% w 2013 r. (do 8,7\% dla ogólnej pomocy publicznej w tym roku). Przewaga instrumentów pomocy czynnej była więc jeszcze większa niż w przypadku ogólnej pomocy publicznej. 
Pobrane z czasopisma Annales H - Oeconomia http://oeconomia.annales.umcs.pl Data: 26/04/2023 02:39:23

PODATKOWE INSTRUMENTY POMOCY PUBLICZNEJ

Tab. 6. Podmioty udzielające pomocy de minimis

\begin{tabular}{|l|c|c|c|c|c|c|}
\hline \multirow{2}{*}{\multicolumn{1}{|c|}{ Nazwa instytucji }} & \multicolumn{6}{c|}{ A2+C2 } \\
\cline { 2 - 7 } & \multicolumn{2}{|c|}{ Wartość pomocy w mln zl } & \multicolumn{3}{c|}{ Udział w \% } \\
\cline { 2 - 7 } & 2011 & 2012 & 2013 & 2011 & 2012 & 2013 \\
\hline $\begin{array}{l}\text { Dyrektorzy izb skarbowych/ } \\
\text { celnych oraz naczelnicy } \\
\text { urzędów skarbowych/celnych }\end{array}$ & 183,9 & 91,3 & 83,8 & 44,15 & 30,05 & 22,75 \\
\hline $\begin{array}{l}\text { Prezydenci/burmistrzowie } \\
\text { miast oraz wójtowie gmin }\end{array}$ & 203,9 & 120,7 & 131,5 & 48,96 & 39,73 & 35,69 \\
\hline Inne podmioty & 28,7 & 91,8 & 153,1 & 6,89 & 30,22 & 41,56 \\
\hline Ogółem & 416,5 & 303,8 & 368,4 & 100,00 & 100,00 & 100,00 \\
\hline
\end{tabular}

Źródło: opracowanie własne na podstawie raportów o pomocy de minimis w Polsce udzielanej przedsiębiorcom w poszczególnych latach, UOKiK.

W latach 2011 i 2012 najwięcej pomocy de minimis z wykorzystaniem instrumentów podatkowych i parapodatkowych $(\mathrm{A} 2+\mathrm{C} 2)$ udzieliły JST oraz izby i urzędy skarbowe, natomiast w 2013 r. - inne podmioty (tab. 6). Warto podkreślić, że kwoty pomocy de minimis udzielonej w tej formie przez prezydentów i burmistrzów miast oraz wójtów gmin były wyższe niż kwoty udzielonej przez te podmioty ogólnej pomocy publicznej o charakterze biernym. Wynosiły one odpowiednio: w $2011 \mathrm{r}$. 203,9 mln zł (pomoc de minimis) i 113,7 mln zł (pomoc ogólna), w 2012 r. - 120,7 mln zł i 109,3 mln zł, w 2013 r. - 131,5 mln zł i 110,3 mln zł. Przyczyny tych różnic zostały już wcześniej zasygnalizowane, a wiążą się ze specyfiką pomocy de minimis i jej beneficjentów. $Z$ kolei charakter organów udzielających najwięcej pomocy oznaczającej uszczuplenie wpływów budżetowych świadczy o tym, że dominują tu instrumenty podatkowe, dlatego zasadne są wnioski odnoszące się zarówno do całej grupy instrumentów pomocy biernej $(\mathrm{A} 2+\mathrm{C} 2)$, jak i do instrumentów stricte podatkowych.

\section{Podsumowanie}

W świetle powyższych uwag, na podstawie przeprowadzonej analizy ogólnej pomocy publicznej i pomocy de minimis, nasuwają się następujące wnioski:

1. Instrumenty podatkowe są dominującą formą biernej pomocy publicznej w Polsce, o czym świadczy charakter organów udzielających takiego wsparcia.

2. Polityka udzielania pomocy publicznej w Polsce jest zgodna z zasadami przyjętymi w UE, ponieważ w strukturze ogólnej pomocy publicznej, jak również pomocy de minimis, udział wsparcia udzielonego z wykorzystaniem instrumentów podatkowych i parapodatkowych, a więc w formie biernej, uległ w okresie 2007-2013 znacznemu obniżeniu.

3. Ulgi podatkowe (A2), jako bardziej przejrzysta, preferowana przez Komisję Europejską i zamierzona forma pomocy biernej, są częściej wykorzystywa- 
nym instrumentem wspierania przedsiębiorstw niż umorzenia i odroczenia płatności podatkowych i parapodatkowych (C2).

4. Podatkowe instrumenty pomocy mogą mieć zarówno charakter ratunkowy i restrukturyzacyjny, jak i prorozwojowy, szczególnie gdy stanowią zachętę do inwestowania w określonym regionie lub tworzenia mikro i małych przedsiębiorstw na terenie konkretnej JST.

5. Uszczuplenia wpływów do budżetu państwa i budżetów JST z tytułu wykorzystania instrumentów podatkowych i parapodatkowych mogą być rekompensowane efektami prorozwojowymi takiej pomocy, jednak efekty te występują dopiero w dłuższym okresie.

\section{Bibliografia}

Ambroziak A.A., Krajowa pomoc regionalna w SSE w Polsce, OW SGH, Warszawa 2009.

Jurkowska-Gomułka A., Wsparcie antykryzysowe czy prorozwojowe: dylematy unijnej polityki pomocy publicznej, [w:] S. Piątek (red.), Rola sektora publicznego w okresie kryzysu, WN Wydziału Zarządzania UW, Warszawa 2014.

Komunikat Komisji: Projekt - Zawiadomienie Komisji w sprawie pomocy państwa w rozumieniu art. 107 ust. 1 TFUE, Komisja Europejska, Bruksela, 17 stycznia 2014.

Raporty o pomocy de minimis w Polsce udzielonej przedsiębiorcom w latach 2008-2013, UOKiK.

Raporty o pomocy publicznej $w$ Polsce udzielonej przedsiębiorcom w latach 2007-2013, UOKiK.

Rozporządzenie Komisji (UE) nr 651/2014 z dnia 17 czerwca 2014 r. uznające niektóre rodzaje pomocy za zgodne z rynkiem wewnętrznym w zastosowaniu art. 107 i 108 Traktatu (Dz. U. UE L 187, 26.06.2014).

Woźniak B., Polityka fiskalna i polityka udzielania pomocy publicznej - relacje, uwarunkowania, [w:] A. Alińska (red.), Polityka monetarna i fiskalna a stabilność sektora finansowego, CeDeWu, Warszawa 2012.

Woźniak B., Pomoc publiczna, [w:] B. Pietrzak, Z. Polański, B. Woźniak (red.), System finansowy w Polsce, t. 2, WN PWN, Warszawa 2008.

\section{Fiscal State Aid Instrument}

During the period 2007-2013 grants were the dominant instrument of state aid and de minimis aid in Poland. They were followed by fiscal (passive) instrument, which accounted for $8.7 \%$ of total aid and $6 \%$ of de minimis aid in 2013, mainly in the form of tax relief and exemptions (A2) provided by the tax authorities and local government. The instrument was used as rescue and restructuring aid but also as development aid.

\section{Podatkowe instrumenty pomocy publicznej}

W Polsce w latach 2007-2013 dominującą formę ogólnej pomocy publicznej oraz pomocy de minimis stanowiła pomoc czynna, a nie bierna. Podatkowe i parapodatkowe instrumenty pomocy biernej angażowały w 2013 r. tylko 8,7\% udzielonej pomocy ogólnej i 6\% pomocy de minimis. Były wykorzystywane głównie $\mathrm{w}$ formie ulg i zwolnień podatkowych (A2) przez organy skarbowe oraz JST. Są one używane jako pomoc ratunkowa i restrukturyzacyjna oraz pomoc ukierunkowana prorozwojowo. 